\title{
Study regarding the influence of the NPK fertilizers use in long term trial on heavy metals concentration in wheat grains
}

\author{
Adrian Vuscan - Adrian Timar \\ University of Oradea, Faculty of Environmental Protection, Oradea \\ adyvuscan@yahoo.com
}

SUMMARY

\begin{abstract}
The paper presents research results obtained in stationary experiments, carried out at Agricultural Research and Development Station Oradea, regarding the influence of nitrogen, phosphorus and potassium fertilizers, on $\mathrm{Cd}, \mathrm{Pb}, \mathrm{Cu}, \mathrm{Zn}$ and Ni concentration on wheat grains.

The minimum concentration of cadmium in wheat grains was recorded in the case of the unfertilized plot $N_{0} P_{0} K_{0}, 0.12 \mathrm{mg} \mathrm{kg-1}$, and maximum value $0.22 \mathrm{mg} \mathrm{kg}^{-1}$, was registered at the fertilized plot with $N_{160} P_{80} K_{120}$, relative difference relative to control was $84.2 \%$.

Lead concentration had the lowest value in the unfertilized plot, the value $\left(0.4 \mathrm{mg} \mathrm{kg}^{-1}\right)$ being under the maximum allowed (1.0 mg $\left.\mathrm{kg}^{-1}\right)$. In case of the fertilized plot with $N_{160} P_{80} K_{120}$, the lead concentration had the highest value, $0.47 \mathrm{mg} \mathrm{kg}^{-1}$, but even in this case it was located beneath the maximum limit allowed.

In all four systems of fertilization, copper has not exceeded the maximum allowed limit (5 $\left.\mathrm{mg} \mathrm{kg}^{-1}\right)$, the values have been comprised between $1.68 \mathrm{mg} \mathrm{kg}^{-1}$ at the unfertilized plot and $2.81 \mathrm{mg} \mathrm{kg}^{-1}$ at the fertilized plot with $N_{160} P_{80} K_{120}$. In other plots of fertilization copper had concentrations of $1.97 \mathrm{mg} \mathrm{kg}^{-1}$, at the fertilized plot with $N_{80} P_{40} K_{40}$, and 2.78 at the fertilized plot with $N_{80} P_{80} K_{80}$.

The lowest concentration of zinc, $26.47 \mathrm{mg} \mathrm{kg}^{-1}$, has been registered in the control $N_{0} P_{0} K_{0}$. In the other fertilization plots studied, the zinc

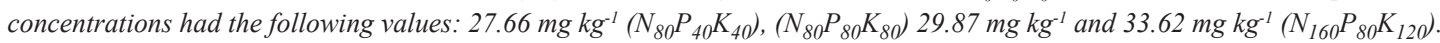

Nickel has registered the lowest value in the unfertilized plot, $3.47 \mathrm{mg} \mathrm{kg}^{-1}$. The fertilized plot with $N_{160} P_{80} K_{120}$ had the highest value $4.94 \mathrm{mg} \mathrm{kg}^{-1}$, with $42.39 \%$ higher compared to the control $\mathrm{N}_{0} P_{0} K_{0}$.
\end{abstract}

Keywords: NPK fertilizers, doses, long term trial, heavy metals, wheat grains

\section{INTRODUCTION}

The environment was contaminated with heavy metals since the time of the original magma of the Earth began to solidify. Excessive concentrations of heavy metals in the soil, without human impact, are the result of natural nitrogen mineralisation (Turner, 1994).

By comparing the amount of heavy metals from naturally and those arising from human activities, Ross (1994) shows that human activities are delivering 13 times more $\mathrm{Cu}$ and 21 times more $\mathrm{Zn}$, than natural processes (Răducu et al., 2012).

In food, the metals with toxic potential come in different ways: with the raw materials as a result of the treatments applied in agriculture, during processing, storage and transportation, from auxiliary materials and from the water used during technological processes, as a result of corrosion processes.

It has been demonstrated that the tolerance of corn, wheat, clover, soybean and sunflower plants to $\mathrm{Pb}$ uptake were differed, the highest concentration of $\mathrm{Pb}$ were determined in corn, clover and soybean and the lowest in sunflower and wheat (El-Aziz et al., 2009).

Orosz et al. (2009), demonstrates that the application of chemical fertilizers with nitrogen, phosphorus and potassium in moderate doses does not lead to significant increases of heavy metals concentrations in grain.

The preluvosoil from Oradea, Romania, is a medium provide with the main nutritive elements, with a weak acid reaction in the ploughing horizon (Ciobanu, 2007; Vuşcan et al., 2010). Many researches on preluvosoil (Samuel et al., 2008; Domuța, 2009) have shown the negative effect of long-term application of nitrogen, as ammonium nitrate, on soil reaction.

The factors which have a negative influence on heavy metals concentration are high level soil content in the $\mathrm{H}^{+}$and $\mathrm{Al}^{3+}, \mathrm{Fe}^{2+}$ and $\mathrm{Mn}^{2+}$ and low level soil content in main nutrients, low activity of microorganisms (Samuel, 2009), and stagnation of water because of unsatisfactory infiltration (Șandor et al., 2008; Brejea, 2010).

This paper has proposed to present the results regarding the influence of nitrogen, phosphorus and potassium fertilizers applied in long term field experiments on $\mathrm{Cd}$, $\mathrm{Pb}, \mathrm{Cu}, \mathrm{Zn}$ and $\mathrm{Ni}$ concentrations in wheat yield.

\section{MATERIAL AND METHOD}

The research data was obtained at the Agricultural Research and Development Station Oradea, using a unique design in all research networks of National Agricultural Research and Development Institute Fundulea.

The investigation has been carried out beginning with the autumn of 1974 in Oradea, in a flat plain area on the third terrace of the Crisul Repede River.

Field experiment with potassium fertilizers was set up in 1974 using a crop rotation: pea - winter wheat maize - sunflower.

The factors researched were the potassium and NP rates applied:

a. potassium rate : $\mathrm{K}_{0}, \mathrm{~K}_{40}, \mathrm{~K}_{80}, \mathrm{~K}_{120}$

b. NP rates: $\mathrm{N}_{0} \mathrm{P}_{0} ; \mathrm{N}_{80} \mathrm{P}_{40} ; \mathrm{N}_{80} \mathrm{P}_{80} ; \mathrm{N}_{160} \mathrm{P}_{80}$. (N was applied like ammonium nitrate, in spring, $\mathrm{P}$ was applied like superphosphate and $\mathrm{K}$ like $\mathrm{KCl}$ in autumn).

The elements of technologies utilized was respected the most recent recommendations in this area.

Grain concentration of heavy metals was determined using the mineralization with sulphuric and perchloric acid mixture method. The results were determined by using the atomic absorption spectrophotometer. 


\section{RESULTS AND DISCUSSION}

Influence of NPK fertilizers on cadmium concentration in wheat

In case of $\mathrm{N}_{0} \mathrm{P}_{0} \mathrm{~K}_{0}$ plot, concentration of cadmium had the $0.12 \mathrm{mg} \mathrm{kg}^{-1}$ value. In the case of the plot fertilized with $\mathrm{N}_{80} \mathrm{P}_{40} \mathrm{~K}_{40}$ the value of cadmium concentration was $0.18 \mathrm{mg} \mathrm{kg}^{-1}$, noticing that the concentration of cadmium increases with $0.06 \mathrm{mg} \mathrm{kg}^{-1}$, respectively with $51.2 \%$ compared to unfertilized plot. The concentration of cadmium has the $0.21 \mathrm{mg} \mathrm{kg}^{-1}$ value at the fertilized plot with $\mathrm{N}_{80} \mathrm{P}_{80} \mathrm{~K}_{80}$ with $0.09 \mathrm{mg} \mathrm{kg}^{-1}$, respectively $80.1 \%$ compared to $\mathrm{N}_{0} \mathrm{P}_{0} \mathrm{~K}_{0}$ plot. Wheat seeds from the fertilized plot with $\mathrm{N}_{160} \mathrm{P}_{80} \mathrm{~K}_{120}$ had a cadmium concentration of $0.22 \mathrm{mg} \mathrm{kg}^{-1}$, with $0.10 \mathrm{mg} \mathrm{kg}^{-1}$ $(84.2 \%)$ higher than the control plot (figure 1).

Figure 1: Influence of NPK fertilizers on cadmium concentration in wheat cultivated in long term trial from Oradea (2010-2012)

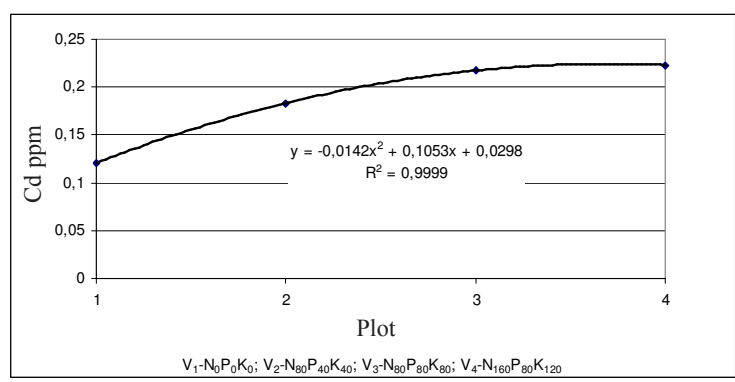

\section{Influence of NPK fertilizers on lead concentration in wheat}

The lead concentration in $\mathrm{N}_{0} \mathrm{P}_{0} \mathrm{~K}_{0}$ plot had $0.40 \mathrm{mg} \mathrm{kg}^{-1}$ value. In the fertilized plot with $\mathrm{N}_{80} \mathrm{P}_{40} \mathrm{~K}_{40}$, lead had $0.43 \mathrm{mg} \mathrm{kg}^{-1}$ concentration, with $0.03 \mathrm{mg} \mathrm{kg}^{-1}$, respectively $9.5 \%$ higher compared to the control plot. In case of the plot fertilized with $\mathrm{N}_{80} \mathrm{P}_{40} \mathrm{~K}_{40}$, the lead concentration had $0.45 \mathrm{mg} \mathrm{kg}^{-1}$ value, with $0.05 \mathrm{mg} \mathrm{kg}^{-1}$, respectively $14.2 \%$ higher than in case of the control plot. In case of the plot fertilized with $\mathrm{N}_{160} \mathrm{P}_{80} \mathrm{~K}_{120}$, lead concentration had a value of $0.47 \mathrm{mg} \mathrm{kg}^{-1}$, with $0.07 \mathrm{mg} \mathrm{kg}^{-1}$ respectively with $19 \%$ higher than the unfertilized plot (figure 2).

Figure 2: Influence of NPK fertilizers on lead concentration in wheat cultivated in long term trial from Oradea (2010-2012)

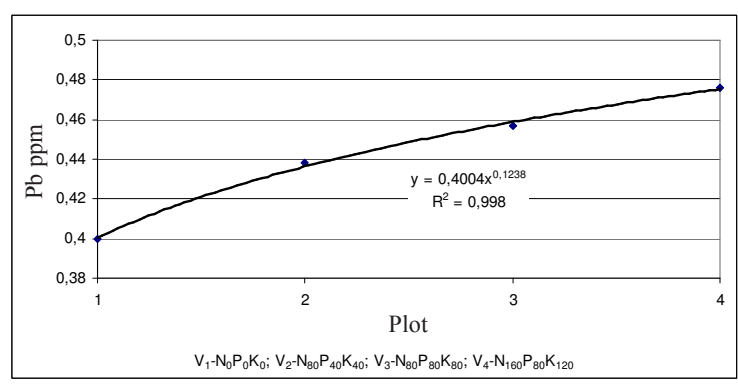

Influence of NPK fertilizers on copper concentration in wheat

The analysed samples from the $\mathrm{N}_{0} \mathrm{P}_{0} \mathrm{~K}_{0}$ plot had $1.68 \mathrm{mg} \mathrm{kg}^{-1}$ copper concentration, and from the fertilized plot with $\mathrm{N}_{80} \mathrm{P}_{40} \mathrm{~K}_{40}$ had $1.97 \mathrm{mg} \mathrm{kg}^{-1}$ value, with
$0.29 \mathrm{mg} \mathrm{kg}^{-1}$, respectively $17.29 \%$ higher. In case of the fertilized plot with $\mathrm{N}_{80} \mathrm{P}_{80} \mathrm{~K}_{80}$, the copper concentration had $2.78 \mathrm{mg} \mathrm{kg}^{-1}$ value, with $1.10 \mathrm{mg} \mathrm{kg}^{-1}$, respectively $65.48 \%$ higher than the unfertilized plot. Copper had a concentration of $2.81 \mathrm{mg} \mathrm{kg}^{-1}$ in the fertilized plot with $\mathrm{N}_{160} \mathrm{P}_{80} \mathrm{~K}_{120}$, with $1.13 \mathrm{mg} \mathrm{kg}^{-1}$, respectively $67.02 \%$ higher than the $\mathrm{N}_{0} \mathrm{P}_{0} \mathrm{~K}_{0}$ plot (figure 3).

Figure 3: Influence of NPK fertilizers on copper concentration in wheat cultivated in long term trial from Oradea (2010-2012)

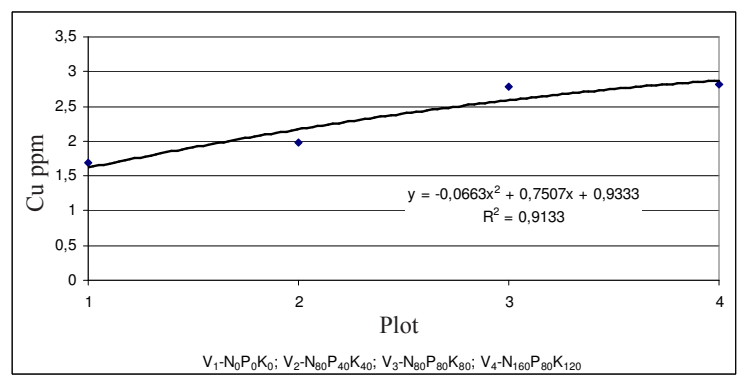

Influence of NPK fertilizers on zinc concentration in wheat

$\mathrm{N}_{0} \mathrm{P}_{0} \mathrm{~K}_{0}$ plot had $26.47 \mathrm{mg} \mathrm{kg}^{-1}$ zinc concentration. In case of the fertilized plot with $\mathrm{N}_{80} \mathrm{P}_{40} \mathrm{~K}_{40}$, the zinc had $27.66 \mathrm{mg} \mathrm{kg}^{-1}$ concentration value, with $1.20 \mathrm{mg} \mathrm{kg}^{-1}$, respectively $4.50 \%$ higher than the $\mathrm{N}_{0} \mathrm{P}_{0} \mathrm{~K}_{0}$ plot. In case of the plot fertilized with $\mathrm{N}_{80} \mathrm{P}_{80} \mathrm{~K}_{80}$, the zinc concentration value was $29.87 \mathrm{mg} \mathrm{kg}^{-1}$ with $3.40 \mathrm{mg} \mathrm{kg}^{-1}$, respectively $12.84 \%$ higher than the $\mathrm{N}_{0} \mathrm{P}_{0} \mathrm{~K}_{0}$ plot. The value of zinc concentration in the $\mathrm{N}_{160} \mathrm{P}_{80} \mathrm{~K}_{120}$ fertilized plot was $33.62 \mathrm{mg} \mathrm{kg}^{-1}$, with $7.16 \mathrm{mg} \mathrm{kg}^{-1}$ respectively $27.01 \%$ higher than the control plot (figure 4).

Figure 4: Influence of NPK fertilizers on zinc concentration in wheat cultivated in long term trial from Oradea (2010-2012)

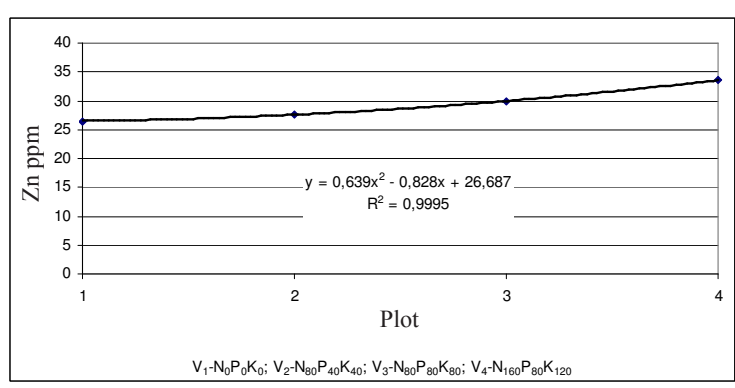

Influence of NPK fertilizers on nickel concentration in wheat

Nickel concentration at the $\mathrm{N}_{0} \mathrm{P}_{0} \mathrm{~K}_{0}$ plot had $3.47 \mathrm{mg} \mathrm{kg}^{-1}$ value. In case of the plot fertilized with $\mathrm{N}_{80} \mathrm{P}_{40} \mathrm{~K}_{40}$, the value of nickel concentration was $4.14 \mathrm{mg} \mathrm{kg}^{-1}$, noting that, nickel concentration increases with $0.67 \mathrm{mg} \mathrm{kg}^{-1}$, respectively $19.19 \%$, compared to the $\mathrm{N}_{0} \mathrm{P}_{0} \mathrm{~K}_{0}$ plot. The plot fertilized with $\mathrm{N}_{80} \mathrm{P}_{80} \mathrm{~K}_{80}$ had $4.74 \mathrm{mg} \mathrm{kg}^{-1}$ value of nickel concentration, with $1.27 \mathrm{mg} \mathrm{kg}^{-1}$, respectively $36.66 \%$ than the $\mathrm{N}_{0} \mathrm{P}_{0} \mathrm{~K}_{0}$ plot. Wheat seeds from the plot fertilized with $\mathrm{N}_{160} \mathrm{P}_{80} \mathrm{~K}_{120}$ had $4.94 \mathrm{mg} \mathrm{kg}^{-1}$ concentration of nickel, with $1.47 \mathrm{mg} \mathrm{kg}^{-1}$ (42.39\%) higher than the $\mathrm{N}_{0} \mathrm{P}_{0} \mathrm{~K}_{0}$ plot (figure 5). 
Figure 5: Influence of NPK fertilizers on nickel concentration in wheat cultivated in long term trial from Oradea (2010-2012)

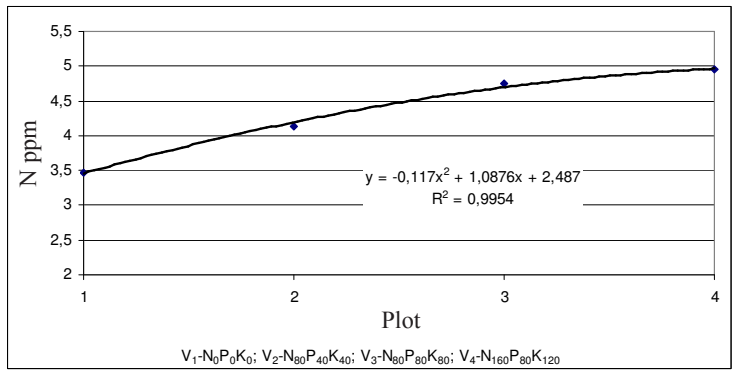

\section{CONCLUSIONS}

Researches carried out during 2010-2012 in a long term experience with doses and combinations of $\mathrm{N}$, P, K located in 1974 to Agricultural Research and Development Station Oradea, have led to the following conclusions on the concentration of heavy metals in wheat grains.

The minimum concentration of cadmium in wheat grains was recorded in the case of the unfertilized plot $\mathrm{N}_{0} \mathrm{P}_{0} \mathrm{~K}_{0}, 0.12 \mathrm{mg} \mathrm{kg}^{-1}$, and maximum value $0.22 \mathrm{mg} \mathrm{kg}^{-1}$, was registered at the fertilized plot with $\mathrm{N}_{160} \mathrm{P}_{80} \mathrm{~K}_{120}$, relative difference to control was $84.2 \%$.
Lead concentration had the lowest value in the unfertilized plot, the value $\left(0.4 \mathrm{mg} \mathrm{kg}^{-1}\right)$ being under the maximum allowed $\left(1.0 \mathrm{mg} \mathrm{kg}^{-1}\right)$. In case of the fertilized plot with $\mathrm{N}_{160} \mathrm{P}_{80} \mathrm{~K}_{120}$, the lead concentration had the highest value, $0.47 \mathrm{mg} \mathrm{kg}^{-1}$, but even in this case it was located beneath the maximum limit allowed.

In all four systems of fertilization, copper did not exceed the maximum allowed limit $\left(5 \mathrm{mg} \mathrm{kg}^{-1}\right)$, the values have been comprised between $1.68 \mathrm{mg} \mathrm{kg}^{-1}$ at the unfertilized plot and $2.81 \mathrm{mg} \mathrm{kg}^{-1}$ at the fertilized plot with $\mathrm{N}_{160} \mathrm{P}_{80} \mathrm{~K}_{120}$. In other plots of fertilization copper had concentrations of $1.97 \mathrm{mg} \mathrm{kg}^{-1}$, at the fertilized plot with $\mathrm{N}_{80} \mathrm{P}_{40} \mathrm{~K}_{40}$, and 2.78 at the fertilized plot with $\mathrm{N}_{80} \mathrm{P}_{80} \mathrm{~K}_{80}$.

The lowest concentration of zinc, $26.47 \mathrm{mg} \mathrm{kg}^{-1}$, has been registered in the control $\mathrm{N}_{0} \mathrm{P}_{0} \mathrm{~K}_{0}$. In the other fertilization plots studied, the zinc concentrations had the following values: $\left.27.66 \mathrm{mg} \mathrm{kg}-1 \mathrm{~N}_{80} \mathrm{P}_{40} \mathrm{~K}_{40}\right)$, $\left(\mathrm{N}_{80} \mathrm{P}_{80} \mathrm{~K}_{80}\right) 29.87 \mathrm{mg} \mathrm{kg}^{-1}$ and $33.62 \mathrm{mg} \mathrm{kg}^{-1}$ $\left(\mathrm{N}_{160} \mathrm{P}_{80} \mathrm{~K}_{120}\right)$.

Nickel reached the lowest value in the unfertilized plot, $3.47 \mathrm{mg} \mathrm{kg}^{-1}$. The fertilized plot with $\mathrm{N}_{160} \mathrm{P}_{80} \mathrm{~K}_{120}$ had the highest value $4.94 \mathrm{mg} \mathrm{kg}^{-1}$, with $42.39 \%$ higher compared to the control $\mathrm{N}_{0} \mathrm{P}_{0} \mathrm{~K}_{0}$.

Our researches highlight that increasing doses of fertilizer, especially those with phosphorus, leads also to the increase of heavy metals concentration.

\section{REFERENCES}

Abd El-Aziz, S. S.-Hoda, Sh.-Ibrahim, E. B. (2009): Uptake and tolerance of some plant species to heavy metals. Egypt. J. Appl. Sci. 24. 1: 329-342.

Brejea, R. (2010): Researches regarding the soil losses produced by erosion in the North Western Romania. Research Journal of Agricultural Science Timişoara. 42. 3: 1-908, 27-32.

Ciobanu, Gh. (2007): Fertilizarea preluvosolurilor din nord-vestul României. Editura Universităţii din Oradea. 34-58.

Orosz, F.- Jakab, S.-Losak, T.-Slezak, K. (2009): Effects of fertilizer application to sweet corn (Zea mays L.) grown on sandy soil. Journal of Environmental Biology. 933-938.

Domuţa, C. (2009): Irigarea culturilor. Editura Universităţii din Oradea. $75-84$.

Răducu, D.-Martini, A.-Pagliai, M.-Vignozzi, N.-Surdu, I.-Ipatie, J. (2012): Micromorphology as a method of assessing the mountain soil sensitivity in order to elaborate the meliorative technology friendly to environment and biodiversity. Analele Universității din Craiova. Agricultură-Montanologie-Cadastru. Lucrări Ştiinţifice. 42.

Ross, S. M. (1994): Source and forms of potentially toxic metals in soil - plant systems. [In: Wiley J. and sons (eds.) Toxic Metal in Soil - Plant System. Chichester. New York. Brisbane. Toronto. Singapore. 5-31.
Samuel, A.D.-Domuța, C.-Ciobanu, C.-Șandor, M. (2008): Field management on soil enzyme activities. Romanian Agricultural Research. 25: 61-68.

Samuel, A. D. (2009): Influence of long term fertilization on soil enzyme activities. Analele Universităţii din Oradea. Fascicula Biologie. 16:113-116.

Şandor, M.-Domuţa, C.-Domuţa, Cr.-Samuel, A. (2008): Crop rotation influence on the wheat yields quantity and quality in the Crisurilor Plain. Lucrările Ştiinţifice Facultatea Agricultură Timişoara. Editura Agroprint - Symphosium: "Trends in European Agriculture Development”. 2: 179.

Turner, A. P. (1994): The response of plants to heavy metals, [In: Wiley J. and sons (eds.) Toxic Metal in Soil - Plant System. Chichester. New York. Brisbane. Toronto. Singapore. 136-150.

Vuscan, A.-- Ciobanu, Gh.- Domuta, C.-Ciobanu, C.-Sandor, M.Bara, L.-Borza, I.-Brejea, R.-Domuţa, Cr. (2010): The Influence of KNP fertilizers in long term field experiments, over agrochemical soil indexes in the preluvosoil conditions from Oradea, România. Research Journal of Agricultural Science Timişoara. 42. 3: 1908, 347-354 
